\title{
Seroprevalence of Hepatitis B Virus in Rural and Urban Areas in Togo
}

\author{
Banfitebiyi Gambogou ${ }^{1 *}$, Holaly E. Gbekley ${ }^{1}$, Mabrouka Bouacha ${ }^{2}$, \\ 1 Laboratoire de Microbiologie et de Contrôle de qualité des Denrées Alimentaires, Ecole Supérieure des \\ Techniques Biologiques et Alimentaires, Université de Lomé, Boulevard Eyadema, BP. 1515, Lomé, Togo. \\ 2 Laboratoire de Biochimie, Université d'Annaba. \\ * Correspondence: Email: dinhog39@gmail.com, Tel: +228 93246922,
}

\begin{abstract}
Infection with the hepatitis B virus (HBV) is a public health problem in many parts of the world, due to its frequency, complications and socio-economic consequences. This study aimed to assess the seroprevalence of hepatitis B virus infection in rural areas and in urban areas. This crosssectional study assessed the prevalence of HBV infection from 2015-2018 at CHR-Sokodé and USP of Ogaro. Biological data of 3000 participants (500 per year in each zone) enrolled and results of HBsAg were assessed during the study period. Female are represented $60 \%$ with average age comprised between [20,29] years old. The high rate of participants enrolled $(45.10 \%)$ are come for the monitoring of pregnancy. The prevalence of VHB during the study are 20.33\% (610/3000), high prevalence $(6.27 \%)$ and the means of VHB prevalence are shown in the age range between [30; 39] with $12.17 \%$ (365/3000) of female and $8.17 \%$ (235/3000) of male are positive after diagnostic detection of HBsAg (antigen of Hepatitis B virus). The prevalence of HBV in rural zone (Ogaro) are $5.23 \%$ and $15.07 \%$ in urban zone (Sokodé) and the high prevalence $(17.50 \%)$ are shown in urban zone. The high prevalence of young suggests that some effort will be due to sensibilized young for HBV sexual transmission and the way of prevention. In addition, some research would be done in research of alternative therapy against this infection.
\end{abstract}

Keywords: Hepatitis B virus, Prevalence of HBsAg, rural and urban zone, Togo.

\section{Introduction}

Hepatitis B virus is a virus that causes inflammatory lesions of the liver. The contamination is mainly sexual, but also blood (contaminated needles, especially drug addicts, tattoos or piercing), and rarely from mother to child during childbirth (1). The virus is highly more contagious than the HIV virus (2). Infection with the hepatitis B virus (HBV) is a public health problem in many parts of the world, due to its frequency, complications and socio-economic consequences. According to the World Health Organization, there are 350 million carriers of the virus in the world (3). Africa and Southeast Asia are the areas of high endemicity (1).

In Africa, more particularly in sub-Saharan Africa, the prevalence rate is between $8 \%$ and $18 \%$, and constitutes an area of high endemicity (4). In this region, the propensity of HBV infection for chronicity makes it the leading cause of cirrhosis and hepatocellular carcinoma (5). These conditions are responsible for high mortality despite the existence of an effective and innocuous vaccine against this virus. The geographic distribution of HIV / AIDS in Africa, overlapping with that of HBV, can influence the natural history of HBV (5-7).

The epidemiology of HBV infection in Togo is difficult to assess because the minnow studies are rare and most often limited populations (8). Thus, any preventive public health action aimed at reducing the mortality and morbidity of an infection must be based on a precise knowledge of the prevalence, incidence, and risk groups (9-12). The city lifestyle and the opportunities offered in terms of risk taking could lead to an increased prevalence of infections in urban areas, and it seems legitimate to wonder whether urban data can be extrapolated to the rural population $(7,13)$. Our work has 
therefore aimed to assess the seroprevalence of hepatitis B virus infection in rural areas and in urban areas and then analyze this prevalence according to age and sex.

\section{Materials and Methods}

This study is a descriptive retrospective study based on serological laboratory records from urban and rural Hospital. It covers a period of three years from January 2015 to December 2017.

\subsection{Data Collection}

Inclusion criteria are all HBsAg (Antigen of Hepatitis B Virus) test done in the period of 2015 to 2017 that were made in the laboratory during the study period and the criteria for non-inclusion are all incomplete records with respect to the study (Age, sex and clinical indication of the HBsAg tracking of the patient during the same period). Total of 3000 records were selected for this study.

\subsection{Study Population and Sample Design}

This cross-sectional study assessed the prevalence of HBV infection from 2015-2018 at CHR-Sokodé and USP of Ogaro. In total, 3000 patients (outcome and hospitalized) (500 per year in each zone) were tested for HBsAg at laboratory during the study period. Biological data such as gender, age and clinical indications of patients were carefully documented. Patients were grouped as follows: 0-9 years, 10-29 years, 30-39 years, 40-49 years and 50 years old and over. Each clinical indication of the HBsAg tracking was included in one of the five following groups: the Clinical Abnormalities Related with the Liver (CARL), the Clinical Abnormalities Not Related with the Liver (CANRL), the Biological Abnormalities (BA), the Pre-Natal Assessment (PNA) and the Systematic Screening (SS). Systematic screening means people who were tested without any symptom, or those with symptoms but these were not related to hepatitis B infection. Data were collected from January 2015 to December 2018 .

\subsection{Assessment of HBV Infection in Study Participants}

To determine HBV infection in the study participants, HBsAg test was performed using AxSYM HBsAg (Abbott Diagnostics, Chicago, USA). It is an Enzyme Linked Immunoassay (ELIZA) for the qualitative detection of HBV surface antigen in the human serum or plasma.

\subsection{Statistical Analysis}

Data were collecte into Microsoft Excel (2013) and statistical analysis performed using SPSS statistics 21.0 software. Univariate comparisons between categorical variables were carried out using the Pearson Chi-Square-test. A P-value less than 0.05 was used to indicate statistical significance.

\section{Results}

\subsection{Study Population Characteristics}

Biological data such as gender, age and clinical indications of participants were represented in table 1 and 2. According to table 1, 60\% of 3000 participants enrolled are female. The minimum and maximum age of participants are respectively 0 to 80 years old with average age comprised between [20 - 29] years old. In table 2, the high rate of participants enrolled $(45.10 \%)$ are come for the monitoring of pregnancy and the lowest rate $(2.67 \%)$ for Clinical Abnormalities Not Related with the Liver such as infectious syndrome, hyperthermia, nephrotic syndrome, sickle cell disease, chronic renal failure on dialysis, hypotension, gastroduodenal reflux and atrioventricular communication. 


\subsection{Prevalence of Hepatitis B virus by gender and age.}

The prevalence of Hepatitis B virus (HBV) between the two localities by gender and age during the period of study are represented in Figure 1. In Fig. 1a, it shown that $12.17 \%$ (365/3000) of female and $8.17 \%$ (235/3000) of male are positive after diagnostic detection of HBsAg. In Fig. 1b, the prevalence of HBsAg during the study are 20.33\% (610/3000), high prevalence (6.27\%) and the means of HBsAg prevalence are shown in the age range between $[30 ; 39]$ and the low prevalence $(0.13 \%)$ in the age range of $[0 ; 9]$

\subsection{Prevalence of Hepatitis B virus by Year and locality.}

The prevalence of HBV by years in urban zone (Sokodé) and rural zone (Ogaro) are represented in Figure 2. During the study period, the prevalence of HBV in rural zone (Ogaro) are 5.23\% and 15.07\% in urban zone (Sokodé). The result shown that there are no statistical difference for the prevalence of HBV in rural zone (Ogaro) during the study period $(\mathrm{p}=0.02)$ but it shown statistical difference $(\mathrm{p}=$ 3.15) in the prevalence of HBV in urban zone with the prevalence of HBV in rural zone. The high prevalence (17.50\%) are shown in urban zone and the low prevalence (4.30\%) in rural zone in 2017 (Fig.2d).

Table:

Table 1: Biological data

\begin{tabular}{|l|l|l|l|}
\hline Age range (years old) & Female & Male & Total \\
\hline $0-9$ & $140(4.67 \%)$ & $90(3.00 \%)$ & $230(7.67 \%)$ \\
\hline $10-19$ & $220(7.33 \%)$ & $156(5.20 \%)$ & $376(12.53 \%)$ \\
\hline $20-29$ & $630(21.00 \%)$ & $266(8.87 \%)$ & $896(29.87 \%)$ \\
\hline $30-39$ & $580(19.33 \%)$ & $246(8.20 \%)$ & $826(27.53 \%)$ \\
\hline $40-49$ & $150(5.00 \%)$ & $366(12.20 \%)$ & $516(17.20 \%)$ \\
\hline 50 et plus & $80(2.67 \%)$ & $76(2.53 \%)$ & $156(5.20 \%)$ \\
\hline Total & $1800(60.00 \%)$ & $1200(40.00 \%)$ & $3000(100.00 \%)$ \\
\hline
\end{tabular}

Mean age $\epsilon[20,29]$ years old with minimum age $=0$ years old and maximum $=65$ years old.

Table 2 : Assessment of clinical indication of participants enrolled

\begin{tabular}{|l|l|l|}
\hline & $\begin{array}{l}\text { Number of individual } \\
\text { screening }\end{array}$ & Percentage \\
\hline Prenatal Assessment & 1353 & $45,10 \%$ \\
\hline Systematic Screening & 743 & $24,77 \%$ \\
\hline Clinical Abnormalities Related with the Liver & 700 & $23,33 \%$ \\
\hline Biological Abnormalities & 124 & $4,13 \%$ \\
\hline Clinical Abnormalities Not Related with the Liver & 80 & $2,67 \%$ \\
\hline Total & 3000 & $100,00 \%$ \\
\hline
\end{tabular}

Figure: 

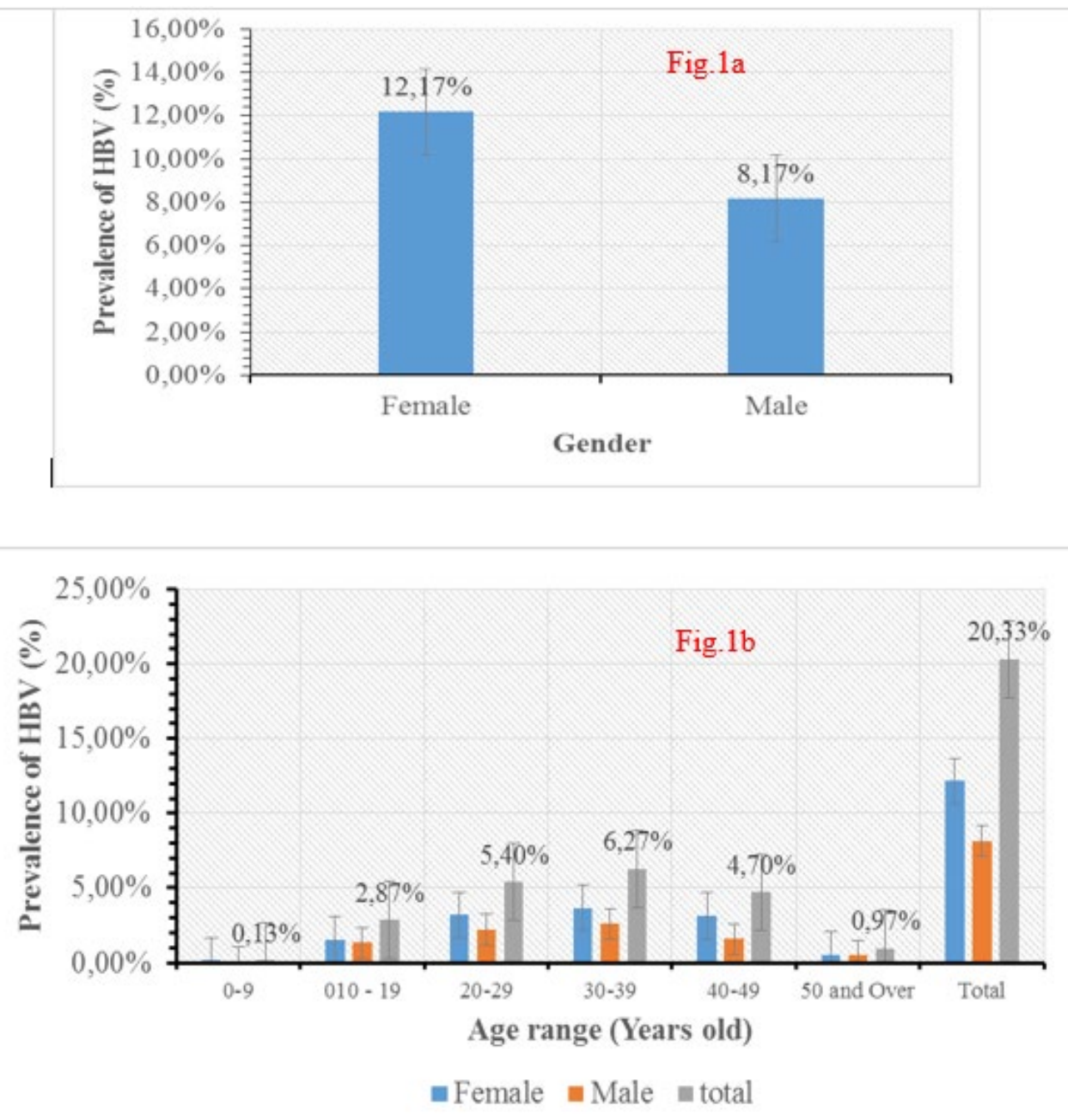

Figure1: Prevalence of HBV by gender and age during 2015 to 2017 in Ogaro and Sokodé (Togo). 

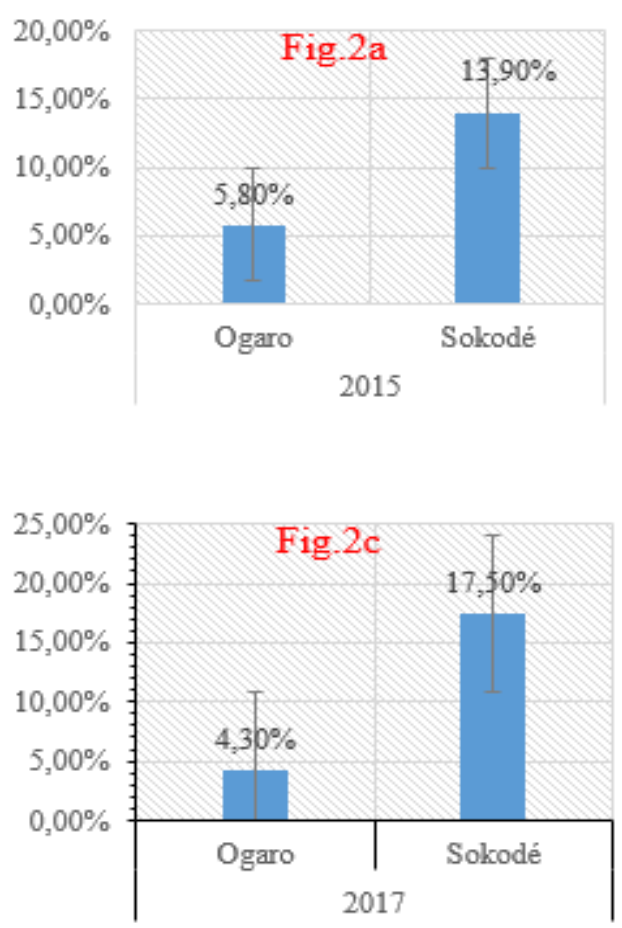
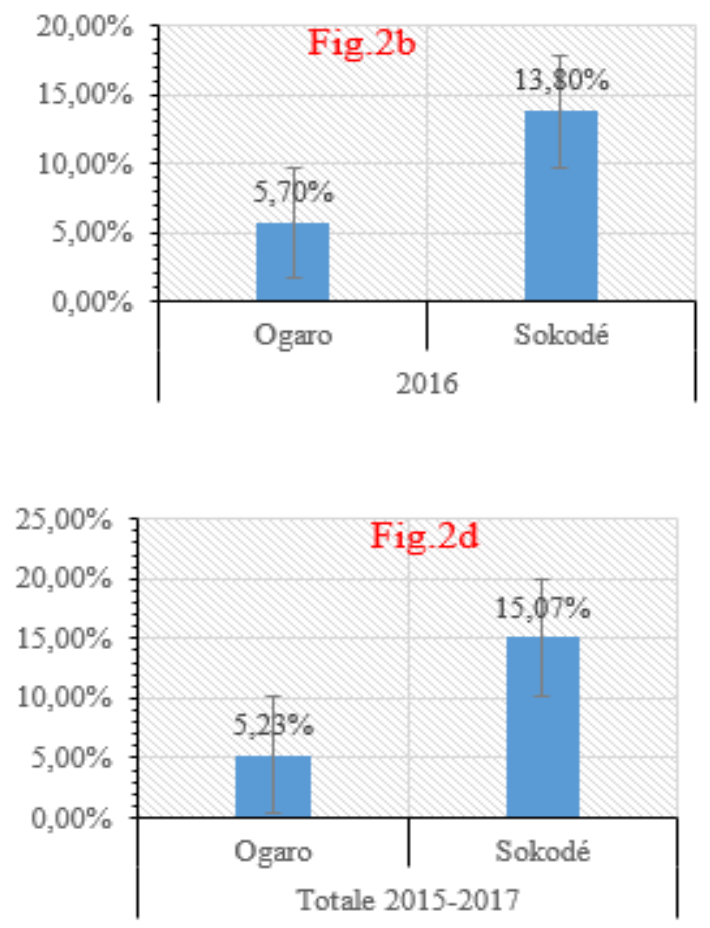

Figure 2: Prevalence of HBV in rural (Ogaro) and urban (Sokodé) zone by years

\section{Discussion}

Worldwide, 2 billion people are known to be infected with hepatitis B virus (3). However, data on the prevalence of chronic viral hepatitis B are varied $(12,14)$. In some countries in sub-Saharan Africa, the prevalence of HBV infection has been estimated to exceed $10 \%$ (15), this reported are correlate with our study. In sub-Saharan such as Burkina Faso, the prevalence of 14.5\% (230/2216) of HBsAg was obtained at Ouagadougou (16). Although the number of females tested was higher compared to males (Table 1), this can be explain by the Prenatal Assessment (45.10\%) (Table 2) (17) or by the fact that male are done VHB diagnostic only they are suspected clinical abnormalities related with the liver, by socioeconomic characteristics $(16,18)$.

In Fig. 1, the prevalence of infected female individuals exceeded that of the male and the number of tested individuals was higher in the age range of 30-39 years old. Interestingly, individuals with age range from 20-39 years old were most infected than children (0-9 years old) and elderly (50 years old and over). The main reason of these differences could be the sexual transmission of HBV. The same result was observed in Madagascar (19), Nigeria (14), Burkina Faso $(5,6)$ and Togo (8) adult population. The, lowest prevalence in children and old (50 years old and more) are explained by genetic reasons in children and in elderly by the death of carriers of the virus because of a reduction of the life expectancy of infected people $(11,20)$. In addition, it has been revealed that African children are infected at birth, but the tests remain negative for many years before the virus reactivates (11). The diagnosis of HBV used here is based on the detection of HBsAg which appears early after the contamination and disappears some few months later (21).

In Fig. 2, the prevalence of HBV in rurale zone (Ogaro) are lowest than urban zone (Sokodé) and the high prevalence observed in urban zone can be explained by the way of life style (13). The 
development of technology and the poverty of the population let them considering sexual activity and using piercing, tattoo as lifestyle of young in African countries $(22,23)$. The other fact are the migration, tourism, and commercial work of the people in urban zone $(11,22,24,25)$.

\section{Conclusions}

High prevalence are observed in young people than children, elderly and in urban zone. The high proportion of female enrolled than male subjected than some effort will be due to sensibilized young for HBV sexual transmission and the way of prevention. In addition, some research would be done in research of alternative therapy by medical plant in according with traditional practionner and government in public health.

Author Contributions: For research articles with several authors, a short paragraph specifying their individual contributions must be provided. The following statements should be used "Conceptualization, B.G. and Y.A.; Methodology, B.G and A.K.O.; Software, A.K.O. H.E.G and B.G.; Validation, M.B. and Y.A.; Formal Analysis, B.G.; Investigation, BG.; Data Curation, M.B, H.E.G and A.K.O.; Writing-Original Draft Preparation, B.G and H.E.G.; Writing-Review \& Editing, B.G. Supervision, Y.A.

Acknowledgments: you acknowledge administration of Lab technician for their help and collaboration.

Conflicts of Interest: The authors declare no conflict of interest.

\section{References.}

1. WHO WHO. Implementation of hepatitis B birth dose vaccination-worldwide, 2016-Mise en oeuvre de la vaccination contre l'hépatite B par une dose à la naissance à l'échelle mondiale, 2016. Weekly Epidemiological Record= Relevé épidémiologique hebdomadaire. 2018;93(7):61-72.

2. Takassi E, Salou, M., Djadou, K. E., Patassi, A., \& Atakouma, Y. D. . Vaccination contre l'hepatite B chez les patients infectes par le VIH au chu Sylvanus Olympio. . Journal de la Recherche Scientifique de l'Université de Lomé. 2017;19(2):359-63.

3. OMS. Weekly Epidemiological Record, 2018, vol. 93, 26 [Full issue]. Weekly Epidemiological Record= Relevé épidémiologique hebdomadaire. 2018;93(26):369-80.

4. Vallois D, Gervais, A., Castanedo, G., Yazdanpanah, Y., \& Rondet, C. . Prévalence de prescriptions de sérologies de l'hépatite $B$ et de vaccins contre l'hépatite $B$ en médecine générale, une étude à partir de l'EGB du SNIIRAM. Médecine et Maladies Infectieuses, . 2017;47(4):S133.

5. Tao I CT, Diarra B, Djigma F, Zohoncon TM, Assih M, Ouermi D, Pietra V, Karou SD, Simpore J. Seroepidemiology of hepatitis B and C viruses in the general population of burkina faso. Hepat Res Treat,. 2014:781843.

6. Sombié R, Bougouma A, Diallo O, Bonkoungou G, Cissé R, Sangare L, Sia R, Serme K, Ilboudo D. Hépatite $\mathrm{B}$ chronique: aspects épidémiologique, diagnostique, thérapeutique et évolutif au centre hospitalier universitaire Yalgado Ouédraogo de Ouagadougou. Journal africain d'hépato-gastroentérologie. 2010;4(1):3-10.

7. Sangaré L, Sombié R, Combasséré A, Kouanda A, Kania D, Zerbo O, Lankoandé J. Transmission anténatale du virus de l'hépatite B en zone de prévalence modérée du VIH, Ouagadougou, Burkina Faso. Bull Soc Pathol Exot. 2009;102(4):226-9.

8. Agbenu E BA, Kolou M, D'Almeida A, Kpotsra A, Dorkenoo A, Redah D. Marqueurs sérologiques utilisés dans la surveillance de l'infection par le virus de l'hépatite B au Togo : état des lieux et propositions. Med Trop. 2008;68:621-4. 
9. Bagny A, Bouglouga O, Djibril M, Lawson A, Kaaga YL, Sama DH, Balaka A, Redah D. Connaissances, attitudes et pratiques du personnel soignant sur le risque de transmission des hépatites virales $B$ et $C$ en milieu hospitalier au Togo. Médecine et Santé Tropicales. 2013;23(3):300-3.

10. Kashosi TM, Mutendela JK, Mwenebitu DL, Maotela JK, Mubagwa K. Contrôle de qualité virologique du sang transfusé dans la ville de Bukavu, Sud Kivu, République Démocratique du Congo. Pan African Medical Journal. 2018;30(193).

11. Kyelem C, Sawadogo A, Yaméogo T, Barro L, Ouédraogo S, Kamboulé E, Ouédraogo A, Poda GE, Zoungrana J, Nacro B. Facteurs de risque de l'hépatite B chez le personnel de santé du Centre Hospitalier Universitaire de Bobo-Dioulasso, Burkina Faso. Journal Africain d'Hépato-Gastroentérologie. 2015;9(1):12-7.

12. OMS. Lignes directrices pour la prévention, les soins et le traitement en faveur des personnes atteintes de l'infection à hépatite B chronique2018.

13. Nalpas B, Zylberberg, H., Dubois, F., Presles, M. A., Gillant, J. C., Lienard, M., ... \& Bréchot, C. . Prévalence des infections par les virus hépatotropes en milieu rural. . Prévalence. 2018.

14. Musa B, Bussell S, Borodo M, Samaila A, Femi O. Prevalence of hepatitis B virus infection in Nigeria, 20002013: a systematic review and meta-analysis. Nigerian journal of clinical practice. 2015;18(2):163-72.

15. Pourette D, Dalsheimer L. VIH et hépatite B chronique chez des migrants subsahariens: des prises en charge différentes affectant le rapport aux soins, les attentes et les recours des patients. Regards croisés sur la santé et la maladie Recherches anthropologiques, recherches cliniques Paris: Éditions des archives contemporaines. 2016:175-96.

16. Birama Diarra ATY, Abdoul Karim Ouattara, Theodora Mahoukèdè Zohoncon, Lassina Traore, Christelle Nadembega, Dorcas Obiri-Yeboah, Justine Yara4,5, Virginio Pietra, Paul Ouedraogo, Alain Bougouma, Rokia Sanogo and Jacques Simpore. World hepatitis day in Burkina Faso, 2017: seroprevalence and vaccination against hepatitis B virus to achieve the 2030 elimination goal. Virology Journal. 2018;15:121. doi: doi.org/10.1186/s12985018-1032-5.

17. Guingané A, Boyer S, Meda N, Sombié R, Gaudart J, Bougouma A. Évaluation d'un nouveau modèle de collaboration entre sages-femmes/maïeuticiens et hépato-gastro-entérologues afin d'améliorer la prise en charge des femmes enceintes infectées par le virus de l'hépatite B et de leurs nouveau-nés dans le district sanitaire urbain de Baskuy au Burkina Faso. Revue d'Épidémiologie et de Santé Publique. 2016;64:S250.

18. Dorkenoo A, Kolou M, Sawadogo H, Fétéké L, Agbenu E, Issa S, Ségbéna A. Évaluation de la protection vaccinale contre le virus de l'hépatite B chez le personnel soignant hospitalier à Lomé. Médecine et Santé Tropicales. 2014;24(3):266-70.

19. Migliani R, Andrianarivelo MR, Rousset D, Rabarijaona L, Randrianarisoa P, Roux J. Séroprévalence de l'hépatite virale B dans la ville de Mahajanga à Madagascar en 1999. Med Trop. 2000;60:146-50.

20. Lo G, Diawara, P. S., Diouf, N. N., Faye, B., Seck, M. C., Sow, K., ... \& Mboup, S. . Prévalence de l'antigène de surface du virus de l'hépatite B (AgHBs) chez les femmes enceintes au laboratoire de l'hôpital Militaire de Ouakam (HMO), Dakar. Médecine d'Afrique noire. 2012;59(5):241-4.

21. Kolou M, Katawa G, Salou M, Gozo-Akakpo KS, Dossim S, Kwarteng A, Prince-David M. High Prevalence of Hepatitis B Virus Infection in the Age Range of 20-39 Years Old Individuals in Lome. The open virology journal. 2017;11:1.

22. Brouard C, Léon, L., Pioche, C., Bousquet, V., Semaille, C., \& Larsen, C. . Dépistage des hépatites B et C en France en 2010, enquête Labo Hep 2010. BEH. 2013;19(205-209). 
23. Bivigou-Mboumba B, Rouet, F., Mouinga-Ondeme, A., Deleplancque, L., Sica, J., Ndjoyi-Mbiguino, A., ... \& François-Souquière, S. . Portage des infections à hépatites virales B, C et E chez les patients infectés par le VIH à Franceville au Gabon: étude transversale rétrospective. . Médecine et Santé Tropicales. 2017;27(3):274-80.

24. Lot F, Antoine, D., Pioche, C., Larsen, C., Che, D., Cazein, F., ... \& Saura, C. . Trois pathologies infectieuses fréquemment rencontrées chez les migrants en France: le VIH, la tuberculose et l'hépatite B. Bull Epidemiol Hebd, . 2012; 17:25-30.

25. Moussa AM, Constant, A., Saleh, A. S., Allarassem, I., Madtoingue, J., Narassem, M., ... \& Choua, O. . Prévalence des Accidents Exposant aux Produits Biologiques Potentiellement Contaminés par les Virus des Hépatites B et C chez les Agents de Santé à Ndjamena. HEALTH SCIENCES AND DISEASES. 2018;19(02). 